\title{
Enhancement of Photovoltaic Performance by Utilizing Readily Accessible Hole Transporting Layer of Vanadium(V) Oxide Hydrate in a Polymer-Fullerene Blend Solar Cell
}

\author{
Youyu Jiang, ${ }^{\dagger}$ Shengqiang Xiao, ${ }^{* \dagger}{ }^{\dagger}$ Biao Xu, ${ }^{\dagger}$ Chun Zhan, ${ }^{\dagger}$ Liqiang Mai, ${ }^{*}$, Xinhui Lu, $^{*},{ }^{\dagger}$ and Wei You ${ }^{*},, \S$ \\ ${ }^{\dagger}$ State Key Laboratory of Advanced Technology for Materials Synthesis and Processing, Wuhan University of Technology, Wuhan, \\ 430070, People's Republic of China \\ ${ }^{\ddagger}$ Department of Physics, the Chinese University of Hong Kong, Hong Kong, People’s Republic of China \\ ${ }^{\S}$ Department of Chemistry, University of North Carolina at Chapel Hill, Chapel Hill, North Carolina 27599-3290, United States
}

Supporting Information

ABSTRACT: Herein, a successful application of $\mathrm{V}_{2} \mathrm{O}_{5} \cdot n \mathrm{H}_{2} \mathrm{O}$ film as hole transporting layer (HTL) instead of PEDOT:PSS in polymer solar cells is demonstrated. The $\mathrm{V}_{2} \mathrm{O}_{5} \cdot n \mathrm{H}_{2} \mathrm{O}$ layer was spin-coated from $\mathrm{V}_{2} \mathrm{O}_{5} \cdot n \mathrm{H}_{2} \mathrm{O}$ sol made from meltingquenching sol-gel method by directly using vanadium oxide powder, which is readily accessible and cost-effective. $\mathrm{V}_{2} \mathrm{O}_{5}$. $n \mathrm{H}_{2} \mathrm{O} \quad(n \approx 1) \mathrm{HTL}$ is found to have comparable work function and smooth surface to that of PEDOT:PSS. For the solar cell containing $\mathrm{V}_{2} \mathrm{O}_{5} \cdot n \mathrm{H}_{2} \mathrm{O} \mathrm{HTL}$ and the active layer of the blend of a novel polymer donor (PBDSe-DT2PyT) and the acceptor of $\mathrm{PC}_{71} \mathrm{BM}$, the PCE was significantly improved to $5.87 \%$ with a $30 \%$ increase over $4.55 \%$ attained with

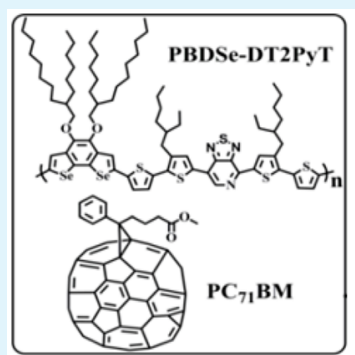

$\mathrm{V}_{2} \mathrm{O}_{5} \cdot \mathrm{nH}_{2} \mathrm{O}$ vs PEDOT:PSS

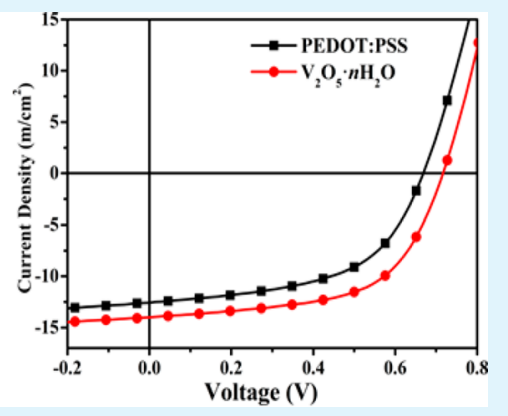

PEDOT:PSS HTL. Incorporation of $\mathrm{V}_{2} \mathrm{O}_{5} \cdot n \mathrm{H}_{2} \mathrm{O}$ as HTL in the polymer solar cell was found to enhance the crystallinity of the active layer, electron-blocking at the anode and the light-harvest in the wavelength range of $400-550 \mathrm{~nm}$ in the cell. $\mathrm{V}_{2} \mathrm{O}_{5} \cdot n \mathrm{H}_{2} \mathrm{O}$ HTL improves the charge generation and collection and suppress the charge recombination within the PBDSeDT2PyT:PC ${ }_{71} B M$ solar cell, leading to a simultaneous enhancement in $V_{\text {oc }} J_{\text {sc }}$ and FF. The $\mathrm{V}_{2} \mathrm{O}_{5} \cdot n \mathrm{H}_{2} \mathrm{O}$ HTL proposed in this work is envisioned to be of great potential to fabricate highly efficient PSCs with low-cost and massive production.

KEYWORDS: polymer solar cell, hole transporting layer, PEDOT:PSS, vanadium(V) oxide hydrate, melting-quenching sol-gel method

\section{INTRODUCTION}

The interfaces between the electrodes (i.e., cathode and anode) and the photoactive layer (e.g., a blend of conjugated polymers with fullerene derivatives) play a very important role in determining the device output in a single-junction bulk heterojunction $(\mathrm{BHJ})$ polymer soar cell (PSC). ${ }^{1-3}$ Both the hole transport layer (HTL) and the electron transport layer (ETL) require careful selection and optimization in order to facilitate the extraction of charge carriers, generated via the dissociation of excitons and the charge separation within the photoactive layer. The most commonly used material as HTL to modify the indium tin oxide (ITO) anode is poly(ethylenedioxythiophene):poly(styrenesulfnate) (PEDOT:PSS), benefiting from its well-established optical and electrical properties including high transparency, suitable work function, and excellent conductivity. ${ }^{4,5}$ Moreover, PEDOT:PSS, commercially available as a water-based solution, is environmentally friendly and only requires low-temperature postbaking process to form a thin film of high quality. Unfortunately, the acidic nature of PEDOT:PSS poses a serious threat to the ITO layer (an oxide), which could deteriorate device performance over time and negatively impact the stability of the practical devices. ${ }^{6,7}$

In recent years, semiconducting transition metal oxides (TMOs) such as $\mathrm{NiO}_{x}, \mathrm{MoO}_{x}, \mathrm{VO}_{x}, \mathrm{WO}_{3}, \mathrm{ReO}_{x}$, and $\mathrm{CuO}_{x}$ have stood out as promising alternatives to PEDOT:PSS, and they have demonstrated comparable device performance to the ones based on PEDOT:PSS, with improved environmental stability of these TMO-based devices. ${ }^{8,9}$ Early studies on these metal oxides typically deposited them as thin films via vacuumbased processes, which are not only incompatible with highthroughput roll-to-roll process but are also not cost-effective. Consequently, solution-processed TMO films have been increasingly explored and significant progress has been made. ${ }^{9}$ However, achieving high quality thin films with these solution-processed metal oxides, in particular, $\mathrm{NiO}_{x},{ }^{10-12}$ $\mathrm{ReO}_{x}{ }^{13} \mathrm{CrO}_{x}{ }^{14}$ and $\mathrm{CuO}_{x}{ }^{15}$ often requires high-temperature $\left(300-600{ }^{\circ} \mathrm{C}\right.$ ) post annealing, $\mathrm{O}_{2}$-plasma/UV-ozone post-

Received: March 6, 2016

Accepted: April 22, 2016

Published: April 22, 2016 
treatment, or a combination of both, to ensure a complete decomposition of inorganic/organic metal salt precursors to form metal oxides.

In this regard, $\mathrm{V}_{2} \mathrm{O}_{5}$ is particularly promising since its thin film formation does not require such undesirable posttreatment processes (e.g., high-temperature annealing). ${ }^{16-20}$ For example, Lira-Cantú et al. recently applied $\mathrm{V}_{2} \mathrm{O}_{5} \cdot 0.5 \mathrm{H}_{2} \mathrm{O}$ prepared from aging metavanadic acid solution over 20 days under ambient conditions, to replace PEDOT:PSS in PSCs. ${ }^{21}$ Although the $\mathrm{V}_{2} \mathrm{O}_{5} \cdot 0.5 \mathrm{H}_{2} \mathrm{O}$ based device showed comparable photovoltaic performance to that of PEDOT:PSS-based counterpart, and good outdoor stability under working conditions, the extremely long aging process ( $>20$ days) to obtain the condensed $\mathrm{V}_{2} \mathrm{O}_{5}$ hydrate sol severely hindered its large scale application in PSCs. On the other hand, vanadium pentoxide sol can be directly made from vanadium oxide powder by a melting-quenching process, in which the molten liquid of $\mathrm{V}_{2} \mathrm{O}_{5}$ prepared in a muffle furnace was quickly poured into controlled amount of distilled water. ${ }^{22-25}$ The limited solubility of crystalline $\mathrm{V}_{2} \mathrm{O}_{5}$ in water and alcohol typically prevents its direct use to prepare films of high quality from solution-based processes. Fortunately, in this melting-quenching process, the highly crystallized $\mathrm{V}_{2} \mathrm{O}_{5}$ is transformed into an amorphous state upon heating at around $800^{\circ} \mathrm{C}$ (i.e., melting), which instead shows higher solubility and can provide target sols with controllable concentrations upon quenching with water. This would allow to directly use vanadium oxide powder-as an alternative to inorganic salts or organometallic precursors - to prepare vanadium oxide sol in water at low cost. Further, this vanadium oxide sol displays high storage stability due to its moisture insensitivity.

We adopted this melt-quenching process to prepare $\mathrm{V}_{2} \mathrm{O}_{5}$ hydrate $\left(\mathrm{V}_{2} \mathrm{O}_{5} \cdot n \mathrm{H}_{2} \mathrm{O}\right)$ thin film as HTL for PSCs. Indeed, the $\mathrm{V}_{2} \mathrm{O}_{5} \cdot n \mathrm{H}_{2} \mathrm{O}$ film after postannealing at $120{ }^{\circ} \mathrm{C}$ is very smooth and has a work function similar to that of PEDOT:PSS. When such $\mathrm{V}_{2} \mathrm{O}_{5} \cdot n \mathrm{H}_{2} \mathrm{O}$ films is used as the HTL for PSC device based on a $\mathrm{BHJ}$ blend of a novel low-band gap polymer donor PBDSe-DT2PyT and [6,6]-phenyl- $\mathrm{C}_{71}$-butyric acid methyl ester $\left(\mathrm{PC}_{71} \mathrm{BM}\right)$ acceptor, we observe a concurrent enhancement in $V_{\mathrm{oc}} J_{\mathrm{sc}}$ and FF of the solar cell devices, leading to a power conversion efficiency (PCE) of $5.87 \%$. This is a $30 \%$ increase in PCE over the $4.55 \%$ of the control device with PEDOT:PSS as the HTL. The role of $\mathrm{V}_{2} \mathrm{O}_{5}$ hydrate HTL in enhancing photovoltaic performance of PBDSeDT2PyT:PC ${ }_{71} B M$ solar cell over PEDOT:PSS HTL is discussed on film crystallinity of the active layer, hole mobility from space charge limited current, reduction in the recombination loss, and the photo-induced carriers generation rate at saturated photocurrent and the charge collection probability within the polymer solar cells.

\section{EXPERIMENTAL SECTION}

Materials and Characterization. The $\mathrm{V}_{2} \mathrm{O}_{5} \cdot n \mathrm{H}_{2} \mathrm{O}$ sol was prepared by using an adapted version of melting-quenching process. ${ }^{23}$ $\mathrm{V}_{2} \mathrm{O}_{5}$ powder $(10 \mathrm{~g})$ was added in a ceramic crucible and heated at 800 ${ }^{\circ} \mathrm{C}$ in a muffle furnace for $30 \mathrm{~min}$. The molten liquid was then quickly poured into distilled water $(500-1000 \mathrm{~mL})$ at room temperature with vigorous stirring. The resultant mixture was filtered three times to afford final brownish $\mathrm{V}_{2} \mathrm{O}_{5}$ hydrate sol.

The detailed synthesis and characterization of novel polymer PBDSe-DT2PyT was presented in Supporting Information. [6,6]Phenyl- $\mathrm{C}_{71}$-butyric acid methyl ester $\left(\mathrm{PC}_{71} \mathrm{BM},>99 \%\right.$, EL device grade) was purchased from Solenne. Thermogravimetric analysis (TGA) of $\mathrm{V}_{2} \mathrm{O}_{5} \cdot n \mathrm{H}_{2} \mathrm{O}$ xerogel was carried out on a NETZSCH syncthermogravimetric analyzer (STA449F3) at a heating rate of 10 ${ }^{\circ} \mathrm{C} \min ^{-1}$ under nitrogen. The X-ray photoelectron spectroscopy (XPS) measurement on $\mathrm{V}_{2} \mathrm{O}_{5} \cdot n \mathrm{H}_{2} \mathrm{O}$ film was performed on a VGScientific ESCA Lab220i-XL electron spectroscopy with an Al $\mathrm{K} \alpha$ X-ray source at an approximately pressure of $3 \times 10^{-9} \mathrm{mbar}$. Samples were prepared by spin-coating $\mathrm{V}_{2} \mathrm{O}_{5}$ sols on silicon wafers. The binding energy of the XPS data was referenced to the $\mathrm{C} 1 \mathrm{~s}$ peak at $284.8 \mathrm{eV}$. The ultraviolet photoelectron spectroscopy (UPS) measurements were carried out by using an equipment of Kratos Axis Ultra DLD with a $\mathrm{He} \mathrm{I}(21.22 \mathrm{eV})$ excitation source in an ultrahigh $3.0 \times$ $10^{-8}$ Torr vacuum. The samples were deposited on ITO substrate by spin coating and biased at $-9 \mathrm{~V}$ to favorably identify the secondaryelectron cutoff from the UPS spectra. AFM morphology of the films was characterized through tapping mode on Multimode 8 SPM at ambient conditions. RTESPA (0.01-0.025 $\Omega \mathrm{cm}$, antimony $(n)$ doped silicon) tips with a spring constant of $20-80 \mathrm{~N} \mathrm{~m}^{-1}$ and frequency of $305-356 \mathrm{kHz}$ were used in imaging. X-ray diffraction (XRD) data of $\mathrm{V}_{2} \mathrm{O}_{5} \cdot n \mathrm{H}_{2} \mathrm{O}$ was recorded by the out-of-plane $\mathrm{XRD}$ profile in reflection mode with a PANalytical X'pert Pro type X-RAY Diffractometer using $\mathrm{Cu} \mathrm{K} \alpha$ radiation $(\lambda=1.540598 \AA)$ at room temperature. The GIWAXS measurements of the pristine polymer films and the blend films of the polymer and $\mathrm{PC}_{71} \mathrm{BM}$ were conducted at 23A SWAXS beamline of a superconductor wiggler at the National Synchrotron Radiation Research Center, Hsinchu, Taiwan, using a $10 \mathrm{keV}$ beam incident at $0.15^{\circ}$ and a C9728DK area detector. Verification of the crystalline structures of PEDOT:PSS or $\mathrm{V}_{2} \mathrm{O}_{5} \cdot n \mathrm{H}_{2} \mathrm{O}$ were done by referring the GIWAXS pattern of the published results to rule out the interference from the HTL. ${ }^{26-29}$

Device Fabrication and Characterization. PSC devices were fabricated with a conventional configuration of indium tin oxide (ITO)/ HTL/PBDSe-DT2PyT:PC ${ }_{71} \mathrm{BM} / \mathrm{Ca}(20 \mathrm{~nm}) / \mathrm{Al}(80 \mathrm{~nm})$. The patterned ITO glass substrates were first cleaned by ultrasonication in DI water, acetone, and isopropyl alcohol sequentially for $10 \mathrm{~min}$, followed by a UV-ozone treatment for $10 \mathrm{~min}$. PEDOT:PSS solution was spin-coated onto the substrates at $4000 \mathrm{rpm}$ for $60 \mathrm{~s}$ and baked at $150{ }^{\circ} \mathrm{C}$ for $30 \mathrm{~min} . \mathrm{V}_{2} \mathrm{O}_{5} \cdot n \mathrm{H}_{2} \mathrm{O}$ was prepared by spin-coating the vanadium pentoxide sol. The thickness of $\mathrm{V}_{2} \mathrm{O}_{5} \cdot n \mathrm{H}_{2} \mathrm{O}$ films was adjusted through control the concentration of the sols. The vanadium pentoxide gel with different concentration (from 3 to $11 \mathrm{mg} \mathrm{mL}^{-1}$ ) was spin-coated on precleaned ITO glass substrates to obtain $\mathrm{V}_{2} \mathrm{O}_{5}$. $n \mathrm{H}_{2} \mathrm{O}$ films with desired thickness (from 5 to $20 \mathrm{~nm}$ ). The water molecules in $\mathrm{V}_{2} \mathrm{O}_{5}$ hydrate are partially eliminated when the $\mathrm{V}_{2} \mathrm{O}_{5}$. $n \mathrm{H}_{2} \mathrm{O}$ thin films are formed on the glass/ITO substrate after annealing at certain temperature. The substrates were then transferred into a glovebox under $\mathrm{N}_{2}$. Subsequently, the active layers were spin-coated from the blend of PBDSe-DT2PyT and $\mathrm{PC}_{71} \mathrm{BM}$ in $o$-DCB solution with a fixed donor concentration of $10 \mathrm{mg} \mathrm{mL}^{-1}$ and dried naturally in the glovebox. Finally, Ca $(20 \mathrm{~nm})$ and $\mathrm{Al}(80 \mathrm{~nm})$ were sequentially thermal evaporated on the top of the active layers as the cathode at a pressure around $4 \times 10^{-6} \mathrm{mbar}$ through a shadow mask that defines 8 devices, each with an area of $9 \mathrm{~mm}^{2}$. The thicknesses of active layers were recorded by a DEKTAK XT profilometer. The statistics of the photovoltaic performance were from at least 20 solar cell devices.

Solar cell performances were tested in a nitrogen-filled glovebox under AM 1.5G irradiation $\left(100 \mathrm{~mW} \mathrm{~cm}^{-2}\right)$ from a $450 \mathrm{~W}$ solar simulator (Newport 94023A-U) calibrated by a NREL certified standard silicon cell. Current versus potential $(J-V)$ curves were recorded with a Keithley 2420 digital source meter. For external quantum efficiency (EQE) tests, devices were transferred by a selfmade testing box into the sample chamber of a 7-SCSpec Spectral Performance of Solar Cell Test System consisting of a 500-W SCS0287ILX500 xenon light source, a 7ISW301 vertical grating spectrometer, a 71FW6 filter wheel, a SR540 chopper and a SR810 lock-in amplifier. The calibration of the incident monochromatic light was carried out with a Hamamatsu S1337-1010 BQ Silicon photo detector.

\section{RESULTS AND DISCUSSION}

Synthesis of the Materials. The polymer PBDSeDT2PyT as shown in Figure 1 was synthesized (Supporting 


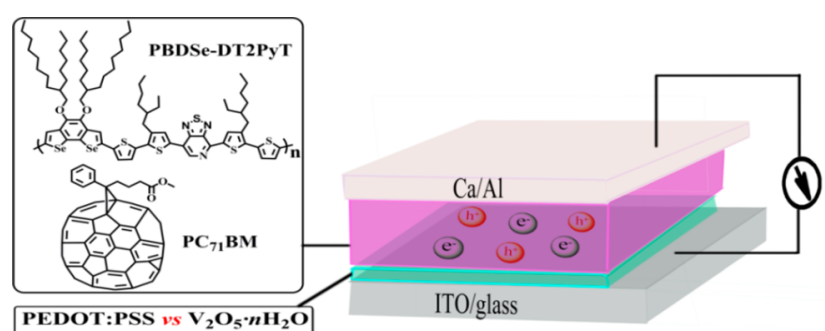

Figure 1. BHJ PSC devices composed of the active layer of PBDSeDT2PyT:PC $\mathrm{PC}_{71} \mathrm{BM}$, the HTL layer of $\mathrm{V}_{2} \mathrm{O}_{5} \cdot n \mathrm{H}_{2} \mathrm{O}$ or PEDOT:PSS, and the electrodes (ITO as the anode and $\mathrm{Ca} / \mathrm{Al}$ as the cathode).

Information, Scheme S1) according to our previous work on PBDSe-DTBT. ${ }^{30}$ PBDSe-DTBT displays both a low optical band gap of $1.71 \mathrm{eV}$ and a deep HOMO level located at -5.37 $\mathrm{eV}$. By introducing thiadiazolo[3,4-c]pyridine based acceptor unit (DT2PyT) to take the place of corresponding benzo[c]$[1,2,5]$ thiadiazole (DTBT) acceptor, PBDSe-DT2PyT shows a lower optical band gap of $1.53 \mathrm{eV}$ while maintaining deep HOMO level at $-5.44 \mathrm{eV}$ (Supporting Information, Figure S1), which may improve light absorption for higher $J_{\mathrm{sc}}$ and matched energy level with $\mathrm{PC}_{71} \mathrm{BM}$ to afford higher $V_{\text {oc }}$.

Vanadium oxides typically exist as layered structures with water molecules intercalated between the layers. The hydrated vanadium pentoxide $\left(\mathrm{V}_{2} \mathrm{O}_{5} \cdot n \mathrm{H}_{2} \mathrm{O}\right)$ gel has an interlayer spacing ranging from 8.8 to $13.8 \AA$, which can be adjusted by controlling the amount of water inserted. ${ }^{31}$ For this reason, the water content has a direct impact on its optolectronic properties. The formation of the $\mathrm{V}_{2} \mathrm{O}_{5} \cdot n \mathrm{H}_{2} \mathrm{O}$ gel is a complex condensation process. ${ }^{24}$ Neutral precursors of $\mathrm{VO}(\mathrm{OH})_{3}$ are obtained when the molten $\mathrm{V}_{2} \mathrm{O}_{5}$ is added into water. The coordination expansion then occurs when additional nucleophilic water molecules are added, leading to a 6-fold vanadium coordination complex of $\mathrm{VO}(\mathrm{OH})_{3}\left(\mathrm{H}_{2} \mathrm{O}\right)_{2}$. Further condensations due to oxolation along the $\mathrm{H}_{2} \mathrm{O}-\mathrm{V}-\mathrm{OH}$ direction and oxolation reactions of the $\mathrm{OH}$ groups lead to the final vanadium pentoxide gel. To identify the value of $n$ for the resulting $\mathrm{V}_{2} \mathrm{O}_{5}$. $n \mathrm{H}_{2} \mathrm{O}$ films, we annealed the films at different temperatures in ambient conditions according to the thermogravimetric analysis (TGA) of a $\mathrm{V}_{2} \mathrm{O}_{5} \cdot n \mathrm{H}_{2} \mathrm{O}$ xerogel, which was obtained by a freeze-drying process of the as-prepared sol to remove free water molecules. Based on the weight loss shown in the TGA curve (Supporting Information, Figure S2), water was totally eliminated after heating above $330{ }^{\circ} \mathrm{C}$ at which point the crystallization of $\mathrm{V}_{2} \mathrm{O}_{5}$ into rhombic crystalline phase $\left(\alpha-\mathrm{V}_{2} \mathrm{O}_{5}\right)$ occurred. ${ }^{23}$ The number of water molecules $(n)$ in the $\mathrm{V}_{2} \mathrm{O}_{5}$. $n \mathrm{H}_{2} \mathrm{O}$ gel can be estimated based on the weight loss as a function of temperature. For example, $n$ is around 1.4 below 80 ${ }^{\circ} \mathrm{C}, 1.0$ at $120^{\circ} \mathrm{C}, 0.8$ at $150{ }^{\circ} \mathrm{C}, 0.7$ at $200{ }^{\circ} \mathrm{C}$, and 0 above 330 ${ }^{\circ} \mathrm{C}$.

Photovoltaic Properties. Optimization of the PEDOT:PSS based devices was undertaken first. Devices with the configuration ITO/PEDOT:PS / PBD S DT2PyT:PC $\mathrm{P}_{71} \mathrm{BM} / \mathrm{Ca} / \mathrm{Al}$ were optimized by changing the donor/acceptor weight ratio, the active layer thickness, and the concentration of a solvent additive. The optimal polymer: $\mathrm{PC}_{71} \mathrm{BM}$ weight ratio was found to be $1: 1$, and the optimal film thickness of the active layer was approximately $90 \mathrm{~nm}$. Interestingly, the photovoltaic performance of the $\mathrm{BHJ}$ blend was not improved by the addition of a high boiling point solvent additive, 1,8-diiodooctane (DIO), but rather worsened overall (Supporting Information, Table S1). After optimizing the active layer processing, the HTL was switched from PEDOT:PSS to $\mathrm{V}_{2} \mathrm{O}_{5} \cdot n \mathrm{H}_{2} \mathrm{O}$. Because the TGA results clearly show that $n$ is affected by temperature, and the number of water molecules in turn affects the optoelectronic properties, we studied the dependence of device performance on annealing temperature and HTL film thickness. The active layer conditions were kept the same as those optimized for the PEDOT:PSS based solar cells. The current-voltage $(J-V)$ characteristics of the optimized $\mathrm{BHJ}$ solar cells containing $\mathrm{V}_{2} \mathrm{O}_{5} \cdot n \mathrm{H}_{2} \mathrm{O}$ and PEDOT:PSS HTLs are displayed in Figure 2 and relevant photovoltaic parameters are summarized in Tables 1 and 2.

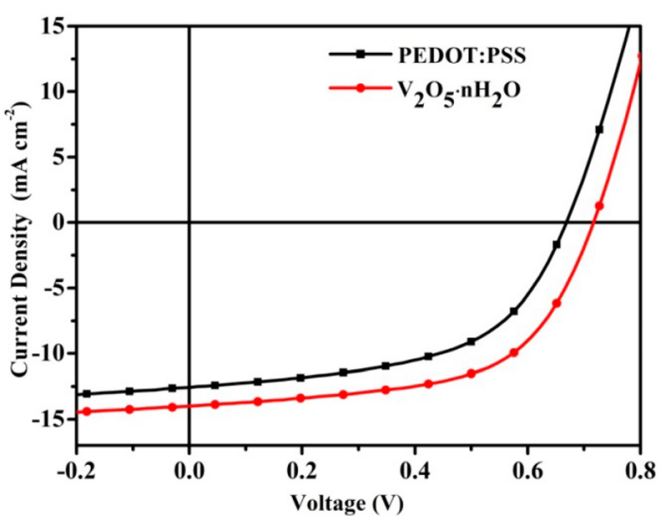

Figure 2. Current-voltage $(J-V)$ curves of optimized PBDSeDT2PyT:PC $\mathrm{P}_{71} \mathrm{BM}$ solar cells with $\mathrm{V}_{2} \mathrm{O}_{5} \cdot n \mathrm{H}_{2} \mathrm{O}$ HTL $(10 \mathrm{~nm}$, annealed at $120^{\circ} \mathrm{C}$ ) and PEDOT:PSS HTL respectively, under illumination of 1 sun at AM 1.5G $\left(100 \mathrm{~mW} \mathrm{~cm}^{-2}\right)$.

The optimized solar cells with a PEDOT:PSS HTL displayed an average PCE of $4.55 \%$, with a $V_{\text {oc }}$ of $0.67 \mathrm{~V}$, a $J_{\text {sc }}$ of $12.53 \mathrm{~mA}$ $\mathrm{cm}^{-2}$, and a FF of 54\%. After switching to $\mathrm{V}_{2} \mathrm{O}_{5} \cdot n \mathrm{H}_{2} \mathrm{O}$ as a HTL, significant improvement in the PCE was observed, mainly due to simultaneous enhancement of the $V_{\text {oc }}$ to $0.72 \mathrm{~V}$ and the FF to greater than 0.57 . It is noteworthy that the $J_{\mathrm{sc}}$ of the $\mathrm{V}_{2} \mathrm{O}_{5} \cdot n \mathrm{H}_{2} \mathrm{O}$ based solar cells are relatively sensitive to both the annealing temperature and the thickness of the $\mathrm{V}_{2} \mathrm{O}_{5} \cdot n \mathrm{H}_{2} \mathrm{O}$ HTL. We obtained the maximum $J_{\text {sc }}$ of $13.96 \mathrm{~mA} \mathrm{~cm}^{-2}$ when $10 \mathrm{~nm}$ of $\mathrm{V}_{2} \mathrm{O}_{5} \cdot n \mathrm{H}_{2} \mathrm{O}$ was annealed at $120{ }^{\circ} \mathrm{C}$, and therefore observed a remarkable average PCE of $5.87 \%$, a $30 \%$ improvement over the PEDOT:PSS devices. Preliminary testing on the stability of the optimized device with HTL of PEDOT:PSS or $\mathrm{V}_{2} \mathrm{O}_{5} \cdot \mathrm{H}_{2} \mathrm{O}$ was also investigated as a function of storage time in a glovebox in dark without any encapsulation at room temperature. As shown in Figure S3, The device with PEDOT:PSS HTL showed a variation of $\sim 96 \%$ on both the $V_{\mathrm{oc}}$ and $J_{\mathrm{sc}}$ and a variation of $\sim 75 \%$ of the FF after $500 \mathrm{~h}$, leading to the PCE decreased to $\sim 70 \%$. In contrast, the $V_{\text {oc }}$ and $J_{\text {sc }}$ of the device with $\mathrm{V}_{2} \mathrm{O}_{5} \cdot \mathrm{H}_{2} \mathrm{O}$ HTL remains almost unchanged and only the FF decreased to $\sim 93 \%$ after $500 \mathrm{~h}$, leading to the PCE decreased to $\sim 93 \%$ and indicating better device stability.

$\mathrm{X}$-ray Photoelectron and Ultraviolet Photoelectron Spectroscopy Analysis. Given the effectiveness of $\mathrm{V}_{2} \mathrm{O}_{5}$. $n \mathrm{H}_{2} \mathrm{O}$ as a HTL, further characterization of the film was performed. X-ray photoelectron spectroscopy (XPS) was used to study the chemical composition of the $\mathrm{V}_{2} \mathrm{O}_{5} \cdot n \mathrm{H}_{2} \mathrm{O}$ film annealed at $120{ }^{\circ} \mathrm{C}$, which had an $n$ of around 1 . The V $2 \mathrm{p}_{3 / 2}$ and $\mathrm{V} 2 \mathrm{p}_{1 / 2}$ spectra can be fitted by different oxidation states $\left(\mathrm{V}^{5+}\right.$ and $\left.\mathrm{V}^{4+}\right)$ in $\mathrm{V}_{2} \mathrm{O}_{5}$ following the Lorentzian-Gaussian model. As shown in Figure 3a, the characteristic peaks with 
Table 1. Average Photovoltaic Characteristics of PBDSe-DT2PyT:PC ${ }_{71} B M\left(1: 1\right.$ Weight Ratio) Solar Cells Utilizing a $\mathrm{V}_{2} \mathrm{O}_{5}{ }^{*}$ $n \mathrm{H}_{2} \mathrm{O}$ HTL with a Fixed Film Thickness of $10 \mathrm{~nm}$ at Various Annealing Temperatures and Optimized Photovoltaic Performance of PEDOT:PSS-based Device for Comparison

\begin{tabular}{|c|c|c|c|c|c|}
\hline HTL (thickness) & annealing temp $\left({ }^{\circ} \mathrm{C}\right)$ & $V_{\mathrm{oc}}(\mathrm{V})$ & $J_{\mathrm{sc}}\left(\mathrm{mA} \mathrm{cm}{ }^{-2}\right)$ & FF (\%) & PCE (\%) \\
\hline \multirow[t]{4}{*}{$\mathrm{V}_{2} \mathrm{O}_{5} \cdot n \mathrm{H}_{2} \mathrm{O}(10 \mathrm{~nm})$} & RT & $0.72 \pm 0.01$ & $12.47 \pm 0.20$ & $0.57 \pm 0.01$ & $5.14 \pm 0.11$ \\
\hline & 120 & $0.72 \pm 0.01$ & $13.96 \pm 0.12$ & $0.59 \pm 0.02$ & $5.87 \pm 0.16$ \\
\hline & 150 & $0.72 \pm 0.01$ & $12.71 \pm 0.11$ & $0.59 \pm 0.01$ & $5.38 \pm 0.10$ \\
\hline & 200 & $0.72 \pm 0.01$ & $12.40 \pm 0.16$ & $0.60 \pm 0.01$ & $5.37 \pm 0.18$ \\
\hline PEDOT:PSS (40 nm) & 150 & $0.67 \pm 0.01$ & $12.53 \pm 0.12$ & $0.54 \pm 0.01$ & $4.55 \pm 0.11$ \\
\hline
\end{tabular}

Table 2. Average Photovoltaic Parameters of PBDSeDT2PyT: $\mathrm{PC}_{71} \mathrm{BM}$ Solar Cells Utilizing $\mathrm{V}_{2} \mathrm{O}_{5} \cdot n \mathrm{H}_{2} \mathrm{O} \mathrm{HTL}$ Annealed at $120^{\circ} \mathrm{C}$ with Various Film Thicknesses

\begin{tabular}{ccccc}
$\begin{array}{c}\text { thickness } \\
\text { of } \mathrm{V}_{2} \mathrm{O}_{5} \\
n \mathrm{H}_{2} \mathrm{O}\end{array}$ & & & & \\
$\mathrm{HTL}(\mathrm{nm})$ & $V_{\text {oc }}(\mathrm{V})$ & $J_{\text {sc }}\left(\mathrm{mA} \mathrm{cm}^{-2}\right)$ & $\mathrm{FF}(\%)$ & PCE (\%) \\
5 & $0.72 \pm 0.01$ & $12.33 \pm 0.33$ & $0.58 \pm 0.02$ & $5.19 \pm 0.25$ \\
10 & $0.72 \pm 0.01$ & $13.96 \pm 0.12$ & $0.59 \pm 0.02$ & $5.87 \pm 0.16$ \\
16 & $0.73 \pm 0.01$ & $12.75 \pm 0.33$ & $0.58 \pm 0.01$ & $5.41 \pm 0.20$ \\
20 & $0.72 \pm 0.01$ & $12.29 \pm 0.11$ & $0.61 \pm 0.01$ & $5.36 \pm 0.10$ \\
\hline
\end{tabular}

energies at 517.2 and $524.7 \mathrm{eV}$ correspond to $\mathrm{V}^{5+}$, and lower peaks at 516 and $523 \mathrm{eV}$ are commonly attributed to $\mathrm{V}^{4+}$ states. $^{21}$ As calculated from the integral area of the V $2 \mathrm{p}$ peaks, the relative ratio of $\mathrm{V}^{5+}$ to $\mathrm{V}^{4+}$ is found to be around 8.95:1. On the basis of the integration of the $\mathrm{O} 1 \mathrm{~s}$ peaks, the $\mathrm{V}: \mathrm{O}$ ratio is around 1:2.45, indicating the existence of oxygen vacancies in the film, which implies a nonstoichiometric composition of $\mathrm{V}_{2} \mathrm{O}_{5} \cdot n \mathrm{H}_{2} \mathrm{O}$. The presence of the $\mathrm{V}^{4+}$ is due to the partial decomposition of $\mathrm{V}_{2} \mathrm{O}_{5}$ when heated above its melting point and the reduction reaction with water molecules that can occur during the quenching process. Previous studies have shown that small amounts of oxygen vacancies can enhance the electrical properties of TMOs when they are employed as HTLs. ${ }^{19}$ Ultraviolet photoelectron spectroscopy (UPS) was further utilized to examine the energy band structures of the $\mathrm{V}_{2} \mathrm{O}_{5}$. $n \mathrm{H}_{2} \mathrm{O}$ film (Figure 3b). This is particularly relevant for improving the interfacial energy level alignment in solar cells. The work function of the $\mathrm{V}_{2} \mathrm{O}_{5} \cdot n \mathrm{H}_{2} \mathrm{O}$ film spin-coated on an ITO substrate and then annealed at $120{ }^{\circ} \mathrm{C}$ was found to be $5.04 \mathrm{eV}$, which is similar to that of PEDOT:PSS $(\sim 5.1 \mathrm{eV}) .^{5}$ Work function of the interlayers can directly affect the ability to block electrons and the $V_{\text {oc }}$ but the small variation in work function between the $\mathrm{V}_{2} \mathrm{O}_{5} \cdot n \mathrm{H}_{2} \mathrm{O}$ HTL and the PEDOT:PSS HTL indicates that such effects can be neglected in this study. Additionally, $\mathrm{V}_{2} \mathrm{O}_{5} \cdot n \mathrm{H}_{2} \mathrm{O}$ thin films are highly transparent in the visible range, particularly 600-900 nm (Supporting Information, Figure S4), and thus do not directly affect the absorbance in the solar cell.

Morphological Analysis. The surface morphologies of $\mathrm{V}_{2} \mathrm{O}_{5} \cdot n \mathrm{H}_{2} \mathrm{O}$ and PEDOT:PSS films spin-coated on bare ITO substrates were examined by atomic force microscopy (AFM) as shown in Figure 4. Figure $4 \mathrm{a}$ indicates that PEDOT:PSS has

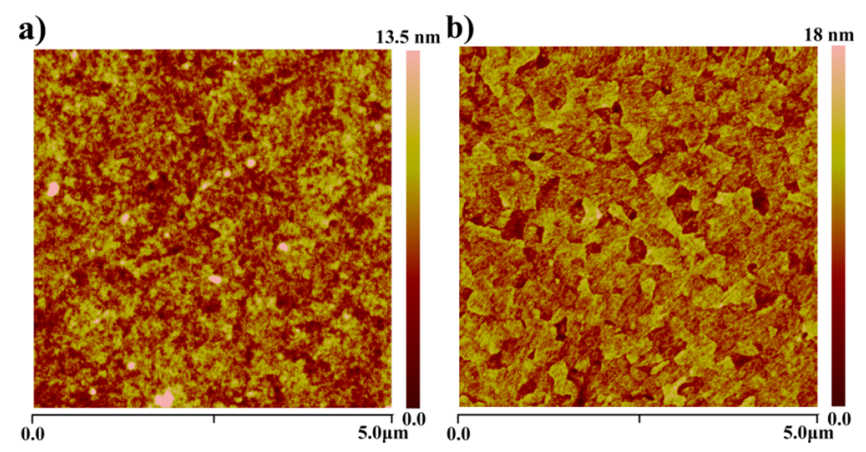

Figure 4. AFM height images $(5 \times 5 \mu \mathrm{m})$ of HTL films spin-coated on ITO: (a) PEDOT:PSS annealed at $150{ }^{\circ} \mathrm{C}$ and (b) $\mathrm{V}_{2} \mathrm{O}_{5} \cdot n \mathrm{H}_{2} \mathrm{O}$ annealed at $120^{\circ} \mathrm{C}$.

a uniform and smooth surface with a root-mean-square (RMS) roughness of $2.08 \mathrm{~nm}$. As for the $\mathrm{V}_{2} \mathrm{O}_{5} \cdot n \mathrm{H}_{2} \mathrm{O}$ film, it also exhibits a very smooth surface with a RMS roughness of 2.13 $\mathrm{nm}$ (Figure 4b). A smooth surface can improve the interface with the photoactive layer and reduce the contact resistance in the solar cells. In order to understand the effect of the HTL on the overall morphology, the effects of both HTLs on the
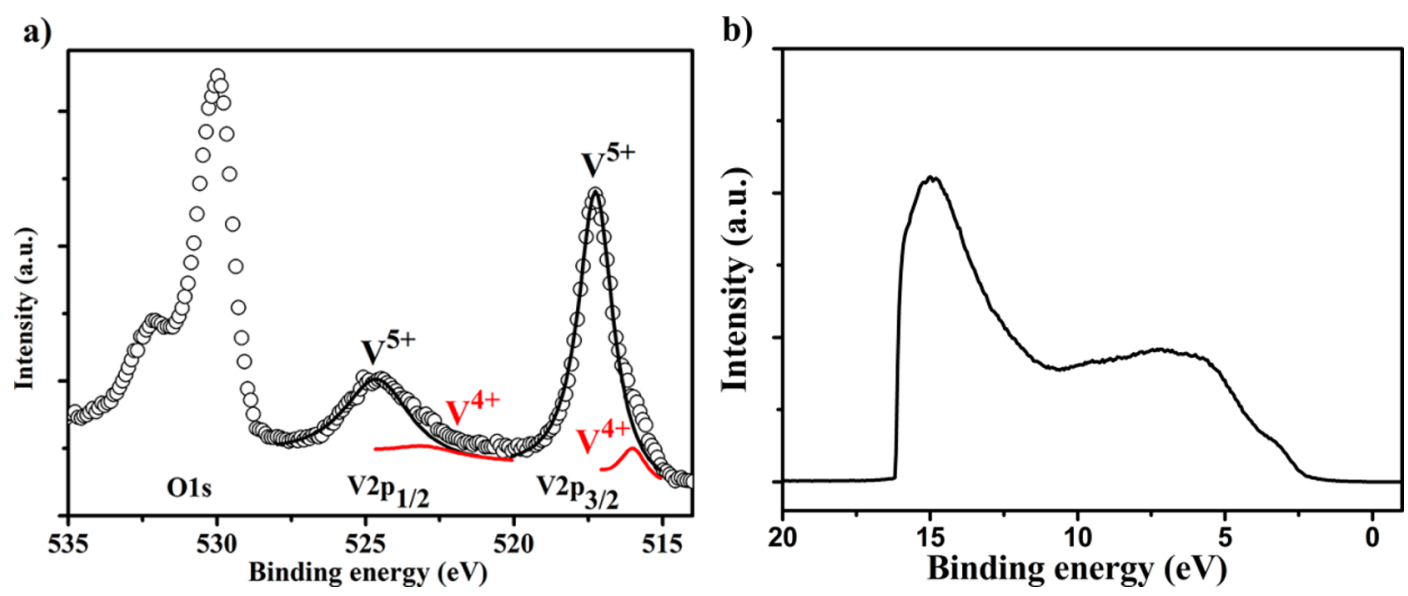

Figure 3. (a) XPS spectra of $\mathrm{V} 2 \mathrm{p}$ and $\mathrm{O} 1 \mathrm{~s}$ of the $\mathrm{V}_{2} \mathrm{O}_{5} \cdot n \mathrm{H}_{2} \mathrm{O}$ film annealed at $120{ }^{\circ} \mathrm{C}$ and (b) UPS spectra of ITO/ $\mathrm{V}_{2} \mathrm{O}_{5} \cdot n \mathrm{H}_{2} \mathrm{O}$ film. 

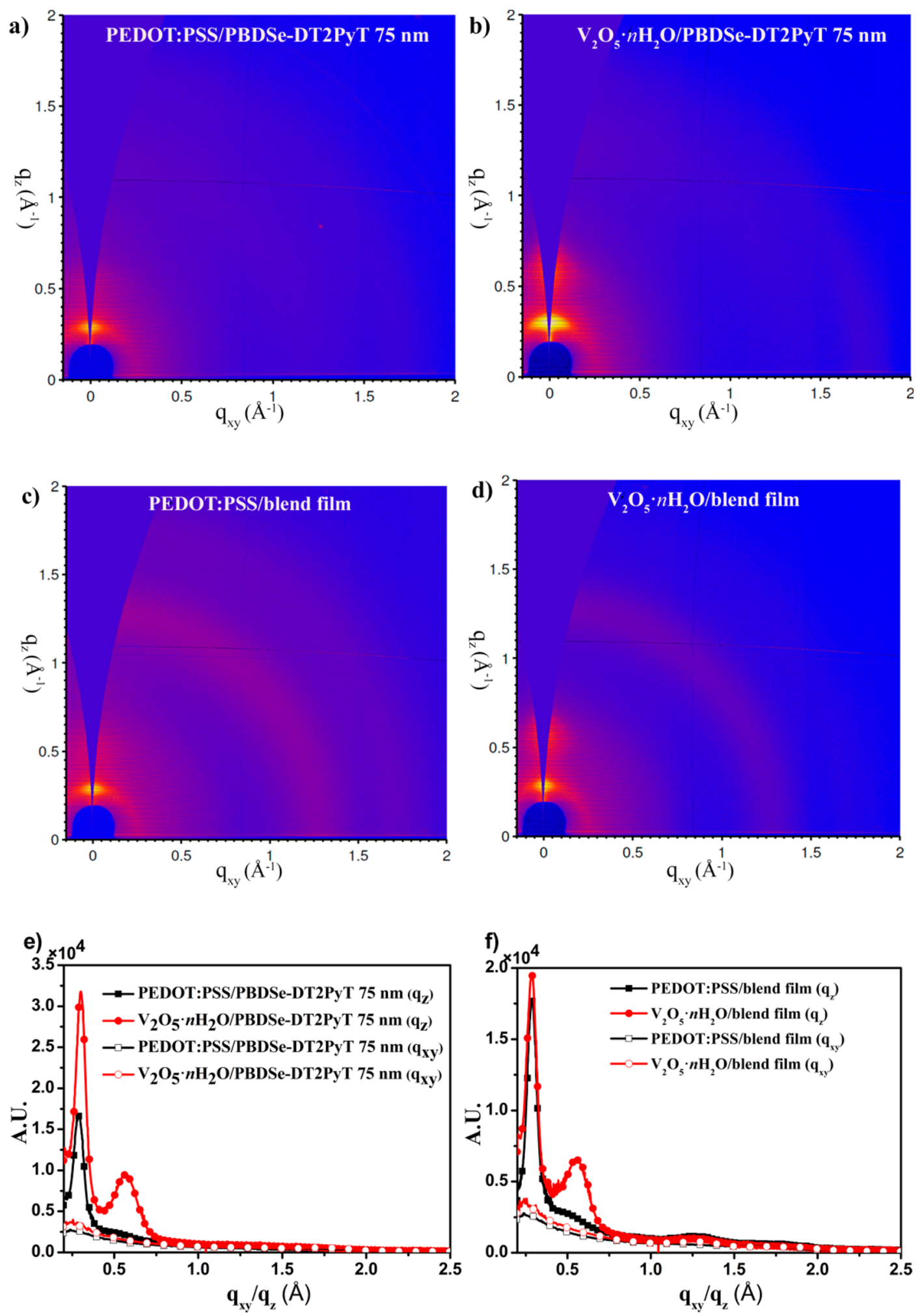

Figure 5. $(\mathrm{a}-\mathrm{d})$ 2D GIWAXS patterns and (e, f) out-of-plane and in-plane data of pristine PBDSe-DT2PyT films and blend films based on PEDOT:PSS and $\mathrm{V}_{2} \mathrm{O}_{5} \cdot n \mathrm{H}_{2} \mathrm{O}$.

morphology of both neat polymer films and the $\mathrm{BHJ}$ blend were studied. The corresponding AFM images of the photoactive layer deposited on both $\mathrm{V}_{2} \mathrm{O}_{5} \cdot n \mathrm{H}_{2} \mathrm{O}$ and PEDOT:PSS are shown in Figure $\mathrm{S} 5$ in Supporting Information. In both cases, the photoactive layer displays a smooth surface with RMS roughness of $\sim 1.9 \mathrm{~nm}$ and comparable phase morphology, implying that surface morphol- ogy of the HTL, and its effect on the surface morphology of the active layer, cannot explain the variation in device performance.

Therefore, two-dimensional grazing incidence wide-angle $\mathrm{X}$ ray scattering (2D-GIWAXS) was employed to explore the structural differences of neat polymer films and $\mathrm{BHJ}$ blend films when deposited on either $\mathrm{V}_{2} \mathrm{O}_{5} \cdot n \mathrm{H}_{2} \mathrm{O}$ or PEDOT:PSS HTLs. Figure 5 shows the detailed GIWAXS profiles in both out-of- 


\section{a)}

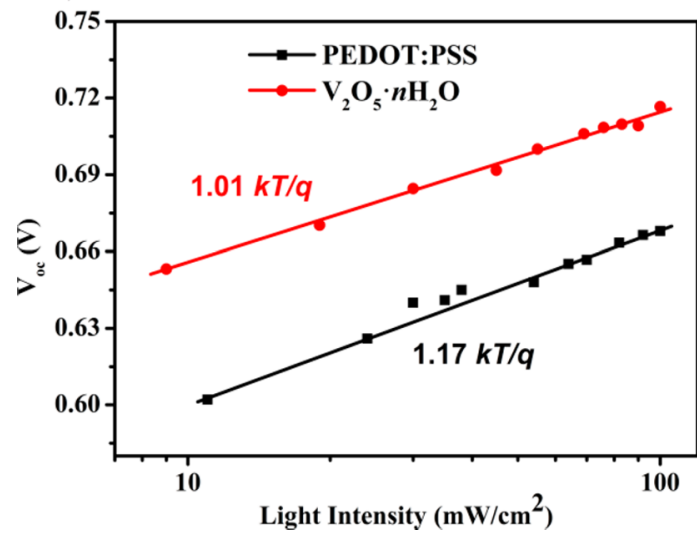

b)

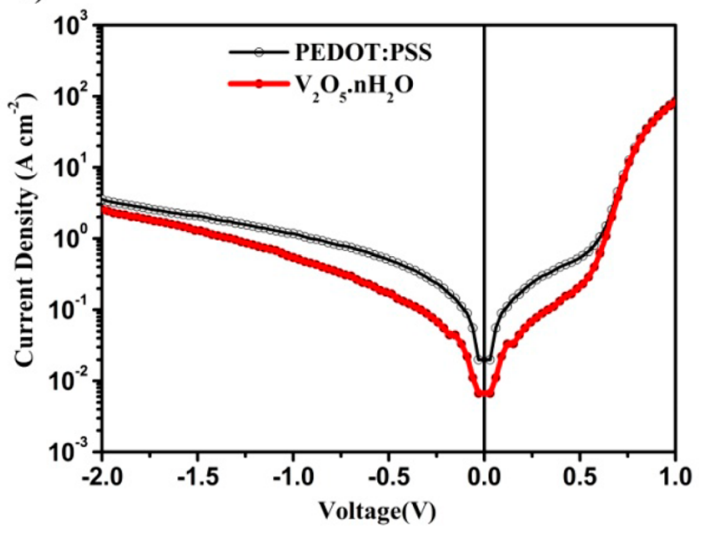

Figure 6. (a) Measured $V_{\mathrm{oc}}$ as a function of light intensity and (b) dark $J-V$ characteristics of the solar cells with either PEDOT:PSS or $\mathrm{V}_{2} \mathrm{O}_{5} \cdot n \mathrm{H}_{2} \mathrm{O}$.

Table 3. Diode Characteristics of $J_{\text {sat }}$ and the Diode Ideality Factor $(n)$ Calculated from Dark $J-V$ Curves and Predicated $V_{\text {oc }}$ and FF

\begin{tabular}{lcccccc}
\multicolumn{1}{c}{$\mathrm{HTL}$} & $J_{\text {sat }}\left(10^{-9} \mathrm{~A} \mathrm{~cm}^{-2}\right)$ & $n$ & $R_{\mathrm{sh}}\left(\Omega \mathrm{cm}^{2}\right)$ & $R_{\mathrm{s}}\left(\Omega \mathrm{cm}^{2}\right)$ & calcd $V_{\text {oc }}(\mathrm{V})$ & calcd FF \\
\hline PEDOT:PSS & 26 & 2.2 & 322 & 9.7 & 0.74 & 0.52 \\
$\mathrm{~V}_{2} \mathrm{O}_{5} \cdot n \mathrm{H}_{2} \mathrm{O}$ & 1.7 & 1.84 & 588 & 8.8 & 0.75 & 0.59 \\
\hline
\end{tabular}

plane and in-plane directions. The GIWAXS pattern of a pure PBDSe-DT2PyT film ( 75 nm) deposited on PEDOT:PSS only exhibited a diffraction (100) peak along the $q_{z}$ axis at a value of $q_{z}$ of $0.29 \AA^{-1}$ (Figure 5e), indicating a preferential edge-on lamellar stacking with a lattice spacing of $21.65 \AA$. Surprisingly, when $\mathrm{V}_{2} \mathrm{O}_{5} \cdot n \mathrm{H}_{2} \mathrm{O}$ was employed as an HTL instead, the intensities of this (100) peak were significantly enhanced compared to that of the PEDOT:PSS based film, indicating a significant increase in the crystallinity of the edgeon PBDSe-DT2PyT lamellae. This increased crystallinity due to the use of the $\mathrm{V}_{2} \mathrm{O}_{5} \cdot n \mathrm{H}_{2} \mathrm{O} \mathrm{HTL}$ was also evidenced by the presence of a clearly identifiable peak in a relatively thin PBDSe-DT2PyT film ( $\sim 5 \mathrm{~nm}$; Supporting Information, Figure S6). This increase in crystallinity is also observed for PBDSeDT2PyT:PC ${ }_{71} \mathrm{BM}$ blend films when PEDOT:PSS was replaced with $\mathrm{V}_{2} \mathrm{O}_{5} \cdot n \mathrm{H}_{2} \mathrm{O}$ as an HTL (Figure 5f). Owing to the higher crystallinity, the hole carrier mobility of the $\mathrm{V}_{2} \mathrm{O}_{5} \cdot n \mathrm{H}_{2} \mathrm{O}$ HTL based solar cell as measured by the space charge limited current (SCLC) method increased to $2 \times 10^{-3} \mathrm{~cm}^{2} \mathrm{~V}^{-1} \mathrm{~s}^{-1}$, almost 4 times the mobility of the PEDOT:PSS HTL based device, 0.54 $\times 10^{-3} \mathrm{~cm}^{2} \mathrm{~V}^{-1} \mathrm{~s}^{-1}$, (Supporting Information, Figure S7), which is beneficial for higher FF. In addition, relatively higher polymer crystallinity may minimize the leakage current loss and recombination loss. ${ }^{32}$ Additionally, all the samples based on the PEDOT:PSS HTL show a weak and wide peak at $q_{z}=0.56 \AA^{-1}$, which was ascribed to the (200) peak of PBDSe-DT2PyT. While for films based on the $\mathrm{V}_{2} \mathrm{O}_{5} \cdot n \mathrm{H}_{2} \mathrm{O} \mathrm{HTL}$, although stronger diffraction peaks were depicted, we cannot identify its influence on the (200) peak of PBDSe-DT2PyT since the diffraction peak of the layered structure with a corresponding $d$ spacing of $11.18 \AA$ in the $\mathrm{V}_{2} \mathrm{O}_{5} \cdot n \mathrm{H}_{2} \mathrm{O}$ film overlapped in this area (as determined in the X-ray diffraction pattern; Supporting Information, Figure S6). This is commonly observed for $\mathrm{V}_{2} \mathrm{O}_{5}$ hydrate. ${ }^{24,28,29}$ The identical, distinguishable yet weak halo centered at a value of $q_{z}$ of $1.24 \AA^{-1}$ in all the $\mathrm{BHJ}$ blend films originates from $\mathrm{PC}_{71} \mathrm{BM}$. These results demonstrate that the $\mathrm{V}_{2} \mathrm{O}_{5} \cdot n \mathrm{H}_{2} \mathrm{O} \mathrm{HTL}$ improves the crystallinity of the donor polymer in the $\mathrm{BHJ}$ morphology, which in turn enhanced the transport of holes within the solar cells.

Electrical Characteriaztion of Photovoltaic Devices. Having understood the effect of the $\mathrm{V}_{2} \mathrm{O}_{5} \cdot n \mathrm{H}_{2} \mathrm{O} \mathrm{HTL}$ on the morphology of the active layer, we next investigated the electrical properties of the devices. The $V_{\mathrm{oc}}$ is normally determined by the difference between the HOMO of the donor and the LUMO of the acceptor, and the work function difference between the anode and the cathode in a $\mathrm{BHJ}$ solar cell. ${ }^{33}$ Because the components of the photoactive layer and the work function of the interlayers do not change for PEDOT:PSS and $\mathrm{V}_{2} \mathrm{O}_{5} \cdot n \mathrm{H}_{2} \mathrm{O}$, these cannot account for the observed increase in $V_{\text {oc }}$. To gain deeper insight into the enhanced $V_{\text {oc }}$ we first analyzed charge carrier recombination. $V_{\text {oc }}$ is proportional to light intensity $(I)$ as described by $V_{\text {oc }} \propto(n k T / q) \ln (I)$, where $k$ is the Boltzmann constant, $T$ is the temperature in Kelvin, and $q$ is the elementary charge. ${ }^{34}$ As shown in Figure 6a, the solar cell with the $\mathrm{V}_{2} \mathrm{O}_{5} \cdot n \mathrm{H}_{2} \mathrm{O}$ HTL exhibited a lower slope of $1.01 \mathrm{kT} / \mathrm{q}$, compared to $1.17 \mathrm{kT} / \mathrm{q}$ for the PEDOT:PSS based device which implies reduced Shockley-Read-Hall (SRH) or trap-assisted recombination in the $\mathrm{V}_{2} \mathrm{O}_{5} \cdot n \mathrm{H}_{2} \mathrm{O}$-based device, $^{30,35,36}$ which can be associated with the improved crystallinity of PBDSe-DT2PyT in the BHJ blend as discussed above. Annihilation of charge carriers by recombination, regardless of its type, would induce energy loss, and thus reduce $V_{\mathrm{oc}}$. Therefore, the observed reduced recombination in the $\mathrm{V}_{2} \mathrm{O}_{5} \cdot n \mathrm{H}_{2} \mathrm{O}$ device can help to explain the $V_{\mathrm{oc}}$ enhancement.

The decrease in recombination is further evidenced by the dark saturation current $\left(J_{\text {sat }}\right)$ and the diode ideality factor $(n)$, which reflect the recombination behavior of the devices. These were estimated by fitting the equivalent circuit equation to the dark $J-V$ curves as shown in Figure $6 \mathrm{~b} .{ }^{37-39}$ The resulting parameters are summarized in Table 3. The $\mathrm{V}_{2} \mathrm{O}_{5} \cdot n \mathrm{H}_{2} \mathrm{O}$ HTL effectively reduces the leakage current of the diode at reverse bias in comparison to that of the PEDOT:PSS HTL device, indicative of improved electron-blocking at the anode. Our calculated data show that the $J_{\text {sat }}$ decreases by 1 order of 
a)

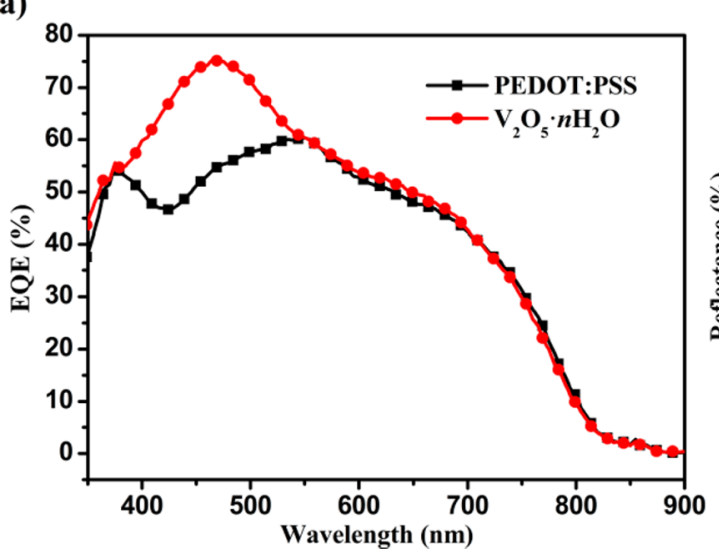

b)

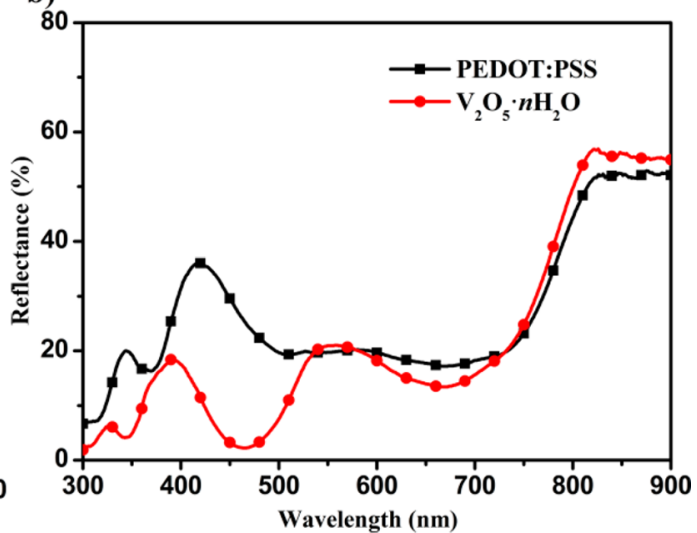

Figure 7. (a) EQE spectra and (b) reflectance spectra of devices with $\mathrm{V}_{2} \mathrm{O}_{5} \cdot n \mathrm{H}_{2} \mathrm{O}$ and PEDOT:PSS, respectively.

a)

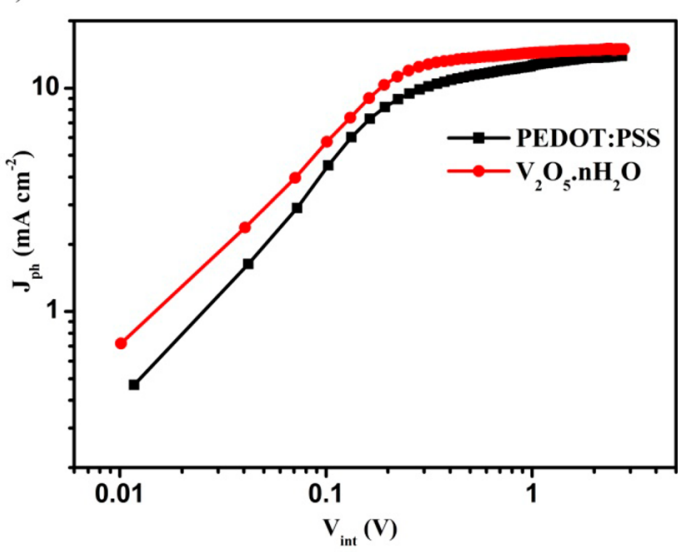

b)

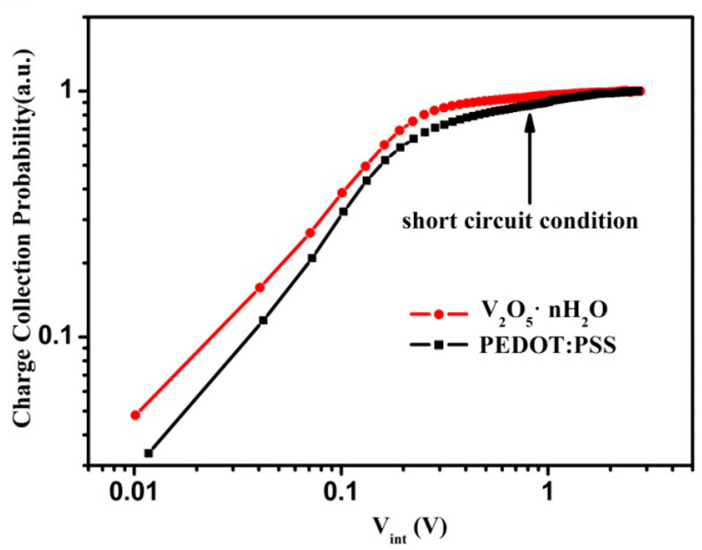

Figure 8. (a) Photocurrent density $\left(J_{\mathrm{ph}}\right)$ and (b) charge collection probability as a function of internal voltage $\left(V_{\text {int }}\right)$ for the solar cells with PEDOT:PSS and $\mathrm{V}_{2} \mathrm{O}_{5} \cdot n \mathrm{H}_{2} \mathrm{O}$.

magnitude, from $2.6 \times 10^{-8} \mathrm{~A} \mathrm{~cm}^{-2}$ with PEDOT:PSS to $1.7 \times$ $10^{-9} \mathrm{~A} \mathrm{~cm}^{-2}$ with $\mathrm{V}_{2} \mathrm{O}_{5} \cdot n \mathrm{H}_{2} \mathrm{O}$. Additionally, the corresponding diode ideality factor $n$ improves to 1.84 from 2.2. These observed trends further indicate that recombination is suppressed in the $\mathrm{V}_{2} \mathrm{O}_{5} \cdot n \mathrm{H}_{2} \mathrm{O}$-based solar cell. On the basis of the simplified expression of $V_{\text {oc }} \approx(n k T / q) \ln \left(J_{\text {sc }} / J_{\text {sat }}\right)$ from the Shockley equation, ${ }^{40,41}$ the changes in $J_{\text {sat }}$ and $n$ track well with the shift in $V_{\text {oc }}$. In particular, a lower $J_{\text {sat }}$ in a solar cell leads to a higher $V_{\text {oc }}$. Indeed, the predicted $V_{\text {oc }}$ is $0.74 \mathrm{~V}$ for PEDOT:PSS and $0.75 \mathrm{~V}$ for $\mathrm{V}_{2} \mathrm{O}_{5} \cdot n \mathrm{H}_{2} \mathrm{O}$ respectively, which is consistent with the trend exhibited by our experimental results. Thus, we can conclude that the $V_{\text {oc }}$ is mainly influenced by the changes in recombination in this $\mathrm{BHJ}$ system.

Because the fill factor of a solar cell is a function of the open circuit voltage $\left(V_{\text {oc }}\right)$ and the diode ideality factor $(n),{ }^{40,42}$ reduced recombination losses may also contributed to the improved FF for the solar cell with the $\mathrm{V}_{2} \mathrm{O}_{5} \cdot n \mathrm{H}_{2} \mathrm{O}$ HTL. ${ }^{43}$ Additionally, however, the series resistance $\left(R_{\mathrm{s}}\right)$ and shunt resistance $\left(R_{\mathrm{sh}}\right)$ are important factors that influence the FF in OPV devices. In a practical equivalent circuit model, FF is determined by such factors in a complex way (see Supporting Information, eqs $\mathrm{S} 2$ and S3). ${ }^{40,42}$ The $\mathrm{V}_{2} \mathrm{O}_{5} \cdot n \mathrm{H}_{2} \mathrm{O}$ based device showed a similar $R_{\mathrm{s}}$, but increased $R_{\mathrm{sh}}\left(588 \Omega \mathrm{cm}^{2}\right)$ relative to the PEDOT:PSS based device ( $322 \Omega \mathrm{cm}^{2}$, in Table 3$)$. It has been reported that higher $R_{\mathrm{sh}}$, which limits current loss in a solar cell, is intimately correlated with larger FF. The calculated
FF of the solar cell with the $\mathrm{V}_{2} \mathrm{O}_{5} \cdot n \mathrm{H}_{2} \mathrm{O}$ HTL is indeed higher than the device with the PEDOT:PSS HTL (0.59 vs 0.52, Table S2). Based on the experimental and theoretical calculations, the FF enhancement in the $\mathrm{V}_{2} \mathrm{O}_{5} \cdot n \mathrm{H}_{2} \mathrm{O}$ based solar cell is a result of both reduced recombination losses and higher shunt resistance.

The suppressed charge recombination mentioned above also contributes to the larger $J_{\text {sc }}$ of the solar cell with the $\mathrm{V}_{2} \mathrm{O}_{5}$. $n \mathrm{H}_{2} \mathrm{O}$ HTL. However, the optical effects of the $\mathrm{V}_{2} \mathrm{O}_{5} \cdot n \mathrm{H}_{2} \mathrm{O}$ HTL on $J_{s c}$ were also investigated. The external quantum efficiency (EQE) spectra of BHJ devices with PEDOT:PSS and $\mathrm{V}_{2} \mathrm{O}_{5} \cdot n \mathrm{H}_{2} \mathrm{O}$ HTLs are shown in Figure 7a. The EQE spectrum of the $\mathrm{V}_{2} \mathrm{O}_{5} \cdot n \mathrm{H}_{2} \mathrm{O}$-based solar cell has a strong peak in the wavelength range from 400 to $550 \mathrm{~nm}$, whereas the PEDOT:PSS device exhibits a deep valley-like response in the same region. We further measured the reflectance loss of the whole device for both devices in question. As shown in Figure $7 \mathrm{~b}$, a clear reflection peak was observed from 400 to 550 $\mathrm{nm}$ for the PEDOT:PSS-based solar cell, whereas there is significantly less reflectance in that range for the $\mathrm{V}_{2} \mathrm{O}_{5} \cdot n \mathrm{H}_{2} \mathrm{O}$ based device. Because the thick cathode layer of $\mathrm{Ca} / \mathrm{Al}$ is nontransparent, the reduced reflectance loss indicates more light-harvesting in the $\mathrm{V}_{2} \mathrm{O}_{5} \cdot n \mathrm{H}_{2} \mathrm{O}$ HTL solar cell. Because both cells utilize similar fabrication conditions and photoactive layers with similar film thicknesses, a direct contribution from the active layer is unlikely and can be ignored (Supporting 
Information, Figure S8). A more plausible explanation is an enhanced distribution of the optical electric field intensity within the active layer for $\mathrm{V}_{2} \mathrm{O}_{5} \cdot n \mathrm{H}_{2} \mathrm{O}$ based device. ${ }^{13,44}$

As a result of increased absorbance, the maximum photo induced carrier generation rate per unit volume $\left(G_{\max }\right)$ in the PSCs will be improved. ${ }^{45-47}$ Figure 8 a shows the plots of the $J_{\text {ph }}$ versus internal voltage $\left(V_{\text {int }}\right)$ of devices with PEDOT:PSS and $\mathrm{V}_{2} \mathrm{O}_{5} \cdot n \mathrm{H}_{2} \mathrm{O}$ respectively, where the $J_{\mathrm{ph}}$ is determined by subtracting the dark current density $\left(J_{D}\right)$ from illumination current $\left(J_{L}\right)$, and $V_{\text {int }}$ is calculated by subtracting the applied voltage $\left(V_{\text {appl }}\right)$ from the built-in voltage $\left(V_{\mathrm{bi}}\right) .^{34,48}$ The $J_{\mathrm{ph}}$ of both devices saturate at high $V_{\text {int }}(>2 \mathrm{~V})$, demonstrating that this internal field is large enough to sweep out all carriers in this system. The estimated saturated photocurrent $\left(J_{\mathrm{ph}, \text { sat }}\right)$ of the solar cell with PEDOT:PSS is $137.0 \mathrm{~A} \mathrm{~m}^{-2}$ and is $148.6 \mathrm{~A} \mathrm{~m}^{-2}$ for the solar cell with $\mathrm{V}_{2} \mathrm{O}_{5} \cdot n \mathrm{H}_{2} \mathrm{O}$. The corresponding $G_{\max }$ $\left(G_{\max }=J_{\text {ph,sat }} / q L\right.$, where $L$ is the thickness of photoactive layer, and $q$ is the elementary charge) of the solar cells is calculated as $0.95 \times 10^{28} \mathrm{~m}^{-3} \mathrm{~s}^{-1}$ and $1.03 \times 10^{28} \mathrm{~m}^{-3} \mathrm{~s}^{-1}$, respectively. Such enhancement in $G_{\max }$ is in good agreement with the improved light harvesting in $\mathrm{V}_{2} \mathrm{O}_{5} \cdot n \mathrm{H}_{2} \mathrm{O}$ HTL-based solar cell. We further compare the charge collection probability $\left(P_{C}=J_{\mathrm{ph}} /\right.$ $\left.J_{\text {ph,sat }}\right)$ with respect to $V_{\text {int }}$ in solar cells with PEDOT:PSS and $\mathrm{V}_{2} \mathrm{O}_{5} \cdot n \mathrm{H}_{2} \mathrm{O}$ HTLs. As shown in Figure $8 \mathrm{~b}$, in comparison with PEDOT:PSS device, the $\mathrm{V}_{2} \mathrm{O}_{5} \cdot n \mathrm{H}_{2} \mathrm{O}$ based device exhibited higher $P_{C}$ across the full $V_{\text {int }}$ range below $1 \mathrm{~V}$. In particular, the $P_{C}$ of the $\mathrm{V}_{2} \mathrm{O}_{5} \cdot n \mathrm{H}_{2} \mathrm{O}$ based solar cell rose to $96 \%$ under the short-circuit conditions, compared to the $88 \%$ of the PEDOT:PSS based solar cell. The increase in $P_{C}$ combined with the increase in light-harvesting lead to a higher $J_{s c}$ in the solar cell with $\mathrm{V}_{2} \mathrm{O}_{5} \cdot n \mathrm{H}_{2} \mathrm{O}$ HTL.

\section{CONCLUSION}

In summary, we demonstrated successful application of highquality $\mathrm{V}_{2} \mathrm{O}_{5} \cdot n \mathrm{H}_{2} \mathrm{O} \mathrm{HTL}$ in PSCs made from meltingquenching sol-gel method by directly using vanadium oxide powder, which is readily accessible and cost-effective. Water content in $\mathrm{V}_{2} \mathrm{O}_{5} \cdot n \mathrm{H}_{2} \mathrm{O}$ HTL can be adjusted by thermal treatment, which gives rise to the deviation of photovoltaic performance of PBDSe-DT2PyT:PC ${ }_{71} \mathrm{BM}$ solar cells. When annealed at $120{ }^{\circ} \mathrm{C}$ to afford $\mathrm{n}$ around $1, \mathrm{~V}_{2} \mathrm{O}_{5} \cdot n \mathrm{H}_{2} \mathrm{O}$ HTL embodied comparable work function and smooth surface to PEDOT:PSS HTL. With optimized thickness around $10 \mathrm{~nm}$ of $\mathrm{V}_{2} \mathrm{O}_{5} \cdot n \mathrm{H}_{2} \mathrm{O}$ HTL, the PCE of PBDSe-DT2PyT:PC ${ }_{71} \mathrm{BM}$ solar cell was significantly improved to $5.87 \%$ with a $30 \%$ increase over $4.55 \%$ attained with PEDOT:PSS HTL. Incorporation of $\mathrm{V}_{2} \mathrm{O}_{5} \cdot n \mathrm{H}_{2} \mathrm{O}$ as HTL in the PSC was found to enhance the crystallinity of the active layer, electron-blocking at the anode and the light-harvest in the wavelength range of $400-550 \mathrm{~nm}$ in the cell measured with reflectance spectroscopy and by the measurement of photo induced carriers generation rate. $\mathrm{V}_{2} \mathrm{O}_{5}$. $n \mathrm{H}_{2} \mathrm{O}$ HTL thus improves the charge generation and collection and suppress the charge recombination within the PBDSeDT2PyT:PC ${ }_{71} \mathrm{BM}$ solar cell, leading to a simultaneous enhancement in $V_{\text {oc }} J_{\text {sc }}$ and FF. The $\mathrm{V}_{2} \mathrm{O}_{5} \cdot n \mathrm{H}_{2} \mathrm{O}$ HTL proposed in this work is envisioned to be of great potential to fabricate highly efficient PSCs with low-cost and massive production.

\section{ASSOCIATED CONTENT}

\section{S Supporting Information}

The Supporting Information is available free of charge on the ACS Publications website at DOI: 10.1021/acsami.6b02824.
Detailed experimental information for the preparation of PBDSe-DT2PyT and its basic optoelectronic properties, the table for average parameters of solar cells with PEDOT:PSS HTL, comparative device stability profiles ( $V_{\text {oc }} J_{\text {so }} \mathrm{FF}$, and PCE vs storage time). AFM topography of BHJ blends and 2D GIWAXS of pristine PBDSeDT2PyT thin films with the thickness of $5 \mathrm{~nm}$ both on $\mathrm{V}_{2} \mathrm{O}_{5} \cdot n \mathrm{H}_{2} \mathrm{O}$ and PEDOT:PSS HTL, XRD measurement of $\mathrm{V}_{2} \mathrm{O}_{5} \cdot n \mathrm{H}_{2} \mathrm{O}$ HTL, $J-V$ plots for hole mobility measurement from space charge limited current method and the dependence of FF on related electrical parameters calculated from the $J-V$ curve of solar cell with $\mathrm{V}_{2} \mathrm{O}_{5} \cdot n \mathrm{H}_{2} \mathrm{O}$ and PEDOT:PSS HTL, respectively. (PDF)

\section{AUTHOR INFORMATION}

\section{Corresponding Authors}

* E-mail: shengqiang@whut.edu.cn.

* E-mail: wyou@unc.edu.

* E-mail: mlq518@whut.edu.cn.

* E-mail: xhlu@phy.cuhk.edu.hk.

Notes

The authors declare no competing financial interest.

\section{ACKNOWLEDGMENTS}

We are grateful for financial support from Wuhan University of Technology and the National Natural Science Foundation of China (NSFC). B. Xu thanks the support from the Undergraduate Training Programs for Innovation and Entrepreneurship of Wuhan University of Technology (20151049701027).

\section{REFERENCES}

(1) Lu, L.; Zheng, T.; Wu, Q.; Schneider, A. M.; Zhao, D.; Yu, L. Recent Advances in Bulk Heterojunction Polymer Solar Cells. Chem. Rev. 2015, 115, 12666-12731.

(2) Kuang, C.; Tang, G.; Jiu, T.; Yang, H.; Liu, H.; Li, B.; Luo, W.; Li, X.; Zhang, W.; Lu, F.; Fang, J.; Li, Y. Highly Efficient Electron Transport Obtained by Doping PCBM with Graphdiyne in PlanarHeterojunction Perovskite Solar Cells. Nano Lett. 2015, 15, 27562762.

(3) Liu, C.; Xu, L.; Chi, D.; Li, Y.; Liu, H.; Wang, J. Synthesis of Novel Acceptor Molecules of Mono- and Multiadduct Fullerene Derivatives for Improving Photovoltaic Performance. ACS Appl. Mater. Interfaces 2013, 5, 1061-1069.

(4) Dou, L.; You, J.; Hong, Z.; Xu, Z.; Li, G.; Street, R. A.; Yang, Y. 25th Anniversary Article: A Decade of Organic/Polymeric Photovoltaic Research. Adv. Mater. 2013, 25, 6642-6671.

(5) Yip, H.-L.; Jen, A. K. Y. Recent Advances in Solution-Processed Interfacial Materials for Efficient and Stable Polymer Solar Cells. Energy Environ. Sci. 2012, 5, 5994-6011.

(6) Norrman, K.; Madsen, M. V.; Gevorgyan, S. A.; Krebs, F. C. Degradation Patterns in Water and Oxygen of an Inverted Polymer Solar Cell. J. Am. Chem. Soc. 2010, 132, 16883-16892.

(7) Nardes, A. M.; Kemerink, M.; de Kok, M. M.; Vinken, E.; Maturova, K.; Janssen, R. A. J. Conductivity, Work Function, and Environmental Stability of PEDOT:PSS Thin Films Treated with Sorbitol. Org. Electron. 2008, 9, 727-734.

(8) Wang, F.; Tan, Z. A.; Li, Y. Solution-Processable Metal Oxides/ Chelates as Electrode Buffer Layers for Efficient and Stable Polymer Solar Cells. Energy Environ. Sci. 2015, 8, 1059-1091.

(9) Chueh, C.-C.; Li, C.-Z.; Jen, A. K. Y. Recent Progress and Perspective in Solution-Processed Interfacial Materials for Efficient and Stable Polymer and Organometal Perovskite Solar Cells. Energy Environ. Sci. 2015, 8, 1160-1189. 
(10) Manders, J. R.; Tsang, S.-W.; Hartel, M. J.; Lai, T.-H.; Chen, S.; Amb, C. M.; Reynolds, J. R.; So, F. Solution-Processed Nickel Oxide Hole Transport Layers in High Efficiency Polymer Photovoltaic Cells. Adv. Funct. Mater. 2013, 23, 2993-3001.

(11) Bai, S.; Cao, M.; Jin, Y.; Dai, X.; Liang, X.; Ye, Z.; Li, M.; Cheng, J.; Xiao, X.; Wu, Z.; Xia, Z.; Sun, B.; Wang, E.; Mo, Y.; Gao, F.; Zhang, F. Low-Temperature Combustion-Synthesized Nickel Oxide Thin Films as Hole-Transport Interlayers for Solution-Processed Optoelectronic Devices. Adv. Energy Mater. 2014, 4, 1301460.

(12) Steirer, K. X.; Ndione, P. F.; Widjonarko, N. E.; Lloyd, M. T.; Meyer, J.; Ratcliff, E. L.; Kahn, A.; Armstrong, N. R.; Curtis, C. J.; Ginley, D. S.; Berry, J. J.; Olson, D. C. Enhanced Efficiency in Plastic Solar Cells via Energy Matched Solution Processed NiOx Interlayers. Adv. Energy Mater. 2011, 1, 813-820.

(13) Tan, Z. A.; Li, L.; Wang, F.; Xu, Q.; Li, S.; Sun, G.; Tu, X.; Hou, X.; Hou, J.; Li, Y. Solution-Processed Rhenium Oxide: A Versatile Anode Buffer Layer for High Performance Polymer Solar Cells with Enhanced Light Harvest. Adv. Energy Mater. 2014, 4, 1300884.

(14) Tu, X.; Wang, F.; Li, C.; Tan, Z. A.; Li, Y. Solution-Processed and Low-Temperature Annealed $\mathrm{CrO}_{\mathrm{x}}$ as Anode Buffer Layer for Efficient Polymer Solar Cells. J. Phys. Chem. C 2014, 118, 9309-9317.

(15) Xu, Q.; Wang, F.; Tan, Z. a.; Li, L.; Li, S.; Hou, X.; Sun, G.; Tu, X.; Hou, J.; Li, Y. High-Performance Polymer Solar Cells with Solution-Processed and Environmentally Friendly $\mathrm{CuO}_{\mathrm{x}}$ Anode Buffer Layer. ACS Appl. Mater. Interfaces 2013, 5, 10658-10664.

(16) Zilberberg, K.; Trost, S.; Meyer, J.; Kahn, A.; Behrendt, A.; Lützenkirchen-Hecht, D.; Frahm, R.; Riedl, T. Inverted Organic Solar Cells with Sol-Gel Processed High Work-Function Vanadium Oxide Hole-Extraction Layers. Adv. Funct. Mater. 2011, 21, 4776-4783.

(17) Zilberberg, K.; Trost, S.; Schmidt, H.; Riedl, T. Solution Processed Vanadium Pentoxide as Charge Extraction Layer for Organic Solar Cells. Adv. Ene. Mater. 2011, 1, 377-381.

(18) Chen, C.-P.; Chen, Y.-D.; Chuang, S.-C. High-Performance and Highly Durable Inverted Organic Photovoltaics Embedding SolutionProcessable Vanadium Oxides as an Interfacial Hole-Transporting Layer. Adv. Mater. 2011, 23, 3859-3863.

(19) Xie, F.; Choy, W. C. H.; Wang, C.; Li, X.; Zhang, S.; Hou, J. Low-Temperature Solution-Processed Hydrogen Molybdenum and Vanadium Bronzes for an Efficient Hole-Transport Layer in Organic Electronics. Adv. Mater. 2013, 25, 2051-2055.

(20) Huang, X.; Zhai, Z.; Yuan, J.; Peng, J.; Yang, T.; Wang, H.-Q.; Ma, W. A Facile Approach to Fabricate Solution-Processable Metal Oxides for Interfacial Layer in Polymer Solar Cells. Org. Electron. 2014, $15,1235-1243$.

(21) Teran-Escobar, G.; Pampel, J.; Caicedo, J. M.; Lira-Cantu, M. Low-Temperature, Solution-Processed, Layered $\mathrm{V}_{2} \mathrm{O}_{5}$ Hydrate as the Hole-Transport Layer for Stable Organic Solar Cells. Energy Environ. Sci. 2013, 6, 3088-3098.

(22) Müller, E. Z. A New Method for Preparation of Colloidal Vanadic Dispersion. Chem. Ind. Kolloide 1911, 8, 302-303.

(23) Wei, Q.; Liu, J.; Feng, W.; Sheng, J.; Tian, X.; He, L.; An, Q.; Mai, L. Hydrated vanadium pentoxide with superior sodium storage capacity. J. Mater. Chem. A 2015, 3, 8070-8075.

(24) Livage, J. Vanadium Pentoxide Gels. Chem. Mater. 1991, 3, $578-593$.

(25) Mai, L.; Tian, X.; Xu, X.; Chang, L.; Xu, L. Nanowire Electrodes for Electrochemical Energy Storage Devices. Chem. Rev. 2014, 114, 11828-11862

(26) Palumbiny, C. M.; Liu, F.; Russell, T. P.; Hexemer, A.; Wang, C.; Müller-Buschbaum, P. The Crystallization of PEDOT:PSS Polymeric Electrodes Probed In Situ during Printing. Adv. Mater. 2015, 27, 3391-3397.

(27) Cruz-Cruz, I.; Reyes-Reyes, M.; Rosales-Gallegos, I. A.; Gorbatchev, A. Y.; Flores-Camacho, J. M.; López-Sandoval, R. Visible Luminescence of Dedoped DBU-Treated PEDOT:PSS Films. J. Phys. Chem. C 2015, 119, 19305-19311.

(28) Espinosa, N.; Dam, H. F.; Tanenbaum, D. M.; Andreasen, J. W.; Jørgensen, M.; Krebs, F. C. Roll-to-Roll Processing of Inverted
Polymer Solar Cells using Hydrated Vanadium(V) Oxide as a PEDOT:PSS Replacement. Materials 2011, 4, 169-182.

(29) An, H.; Mike, J.; Smith, K. A.; Swank, L.; Lin, Y.-H.; Pesek, S. L.; Verduzco, R.; Lutkenhaus, J. L. Highly Flexible Self-Assembled $\mathrm{V}_{2} \mathrm{O}_{5}$ Cathodes Enabled by Conducting Diblock Copolymers. Sci. Rep. 2015, 5,14166 .

(30) Jiang, Y.; Yang, M.; Huang, X.; Gao, J.; Zhan, C.; Xiao, S. A Novel Donor-Acceptor Alternating Copolymer Based on AngularShaped Benzo[2,1-b:3,4-b]Diselenophene for Bulk Heterojunction Solar Cells. Polym. Chem. 2015, 6, 1383-1392.

(31) Whittingham, M. S. Lithium Batteries and Cathode Materials. Chem. Rev. 2004, 104, 4271-4302.

(32) Liu, Y.; Zhao, J.; Li, Z.; Mu, C.; Ma, W.; Hu, H.; Jiang, K.; Lin, H.; Ade, H.; Yan, H. Aggregation and Morphology Control Enables Multiple Cases of High-Efficiency Polymer Solar Cells. Nat. Commun. 2014, 5, 5293.

(33) Brabec, C. J.; Cravino, A.; Meissner, D.; Sariciftci, N. S.; Fromherz, T.; Rispens, M. T.; Sanchez, L.; Hummelen, J. C. Origin of the Open Circuit Voltage of Plastic Solar Cells. Adv. Funct. Mater. 2001, 11, 374-380.

(34) Cowan, S. R.; Roy, A.; Heeger, A. J. Recombination in PolymerFullerene Bulk Heterojunction Solar Cells. Phys. Rev. B: Condens. Matter Mater. Phys. 2010, 82, 245207.

(35) Kyaw, A. K. K.; Wang, D. H.; Gupta, V.; Leong, W. L.; Ke, L.; Bazan, G. C.; Heeger, A. J. Intensity Dependence of Current-Voltage Characteristics and Recombination in High-Efficiency SolutionProcessed Small-Molecule Solar Cells. ACS Nano 2013, 7, 4569-4577.

(36) Proctor, C. M.; Kim, C.; Neher, D.; Nguyen, T.-Q. Nongeminate Recombination and Charge Transport Limitations in Diketopyrrolopyrrole-Based Solution-Processed Small Molecule Solar Cells. Adv. Funct. Mater. 2013, 23, 3584-3594.

(37) Vandewal, K.; Tvingstedt, K.; Gadisa, A.; Inganas, O.; Manca, J. V. On the Origin of the Open-Circuit Voltage of Polymer-Fullerene Solar Cells. Nat. Mater. 2009, 8, 904-909.

(38) He, Z.; Xiao, B.; Liu, F.; Wu, H.; Yang, Y.; Xiao, S.; Wang, C.; Russell, T. P.; Cao, Y. Single-Junction Polymer Solar Cells with High Efficiency and Photovoltage. Nat. Photonics 2015, 9, 174-179.

(39) Qi, B.; Wang, J. Open-Circuit Voltage in Organic Solar Cells. J. Mater. Chem. 2012, 22, 24315-24325.

(40) Qi, B.; Wang, J. Fill Factor in Organic Solar Cells. Phys. Chem. Chem. Phys. 2013, 15, 8972-8982.

(41) Sze, S. M. Physics of Semiconductor Devices. Interscience (Wiley): New York, 1969.

(42) Green, M. A. Accuracy of Analytical Expressions for Solar Cell Fill Factors. Sol. Cells 1982, 7, 337-340.

(43) Stuart, A. C.; Tumbleston, J. R.; Zhou, H.; Li, W.; Liu, S.; Ade, H.; You, W. Fluorine Substituents Reduce Charge Recombination and Drive Structure and Morphology Development in Polymer Solar Cells. J. Am. Chem. Soc. 2013, 135, 1806-1815.

(44) Tan, Z. A.; Li, S.; Wang, F.; Qian, D.; Lin, J.; Hou, J.; Li, Y. High Performance Polymer Solar Cells with As-Prepared Zirconium Acetylacetonate Film as Cathode Buffer Layer. Sci. Rep. 2014, 4, 4691.

(45) Mihailetchi, V. D.; Xie, H. X.; de Boer, B.; Koster, L. J. A.; Blom, P. W. M. Charge Transport and Photocurrent Generation in Poly(3hexylthiophene): Methanofullerene Bulk-Heterojunction Solar Cells. Adv. Funct. Mater. 2006, 16, 699-708.

(46) He, Z.; Zhong, C.; Su, S.; Xu, M.; Wu, H.; Cao, Y. Enhanced Power-Conversion Efficiency in Polymer Solar Cells Using an Inverted Device Structure. Nat. Photonics 2012, 6, 591-595.

(47) Kyaw, A. K. K.; Wang, D. H.; Wynands, D.; Zhang, J.; Nguyen, T.-Q.; Bazan, G. C.; Heeger, A. J. Improved Light Harvesting and Improved Efficiency by Insertion of an Optical Spacer ( $\mathrm{ZnO})$ in Solution-Processed Small-Molecule Solar Cells. Nano Lett. 2013, 13, 3796-3801.

(48) Cowan, S. R.; Street, R. A.; Cho, S.; Heeger, A. J. Transient Photoconductivity in Polymer Bulk Heterojunction Solar Cells: Competition between Sweep-out and Recombination. Phys. Rev. B: Condens. Matter Mater. Phys. 2011, 83, 035205. 